At Claremont, Cala., where I hurriedly examined some 20 nests of this ant, I found the craters to vary from 4-8 inches in diameter, with a central opening $\frac{1}{4}-\frac{3}{4}$ of an inch across. They were in dry, hard soil, often along roads or paths in situations where there was considerable vegetation, either chaparral, live-oaks (Quercus agrifolia) or scrub-oaks ( $Q$. dumosa). In such localities the ants probably obtain their supply of nectar from the galls or from coccids and aphids on the oaks or other components of the chaparral. Mr. Leonard has given a more extensive account of the habits of mojave at Point Loma. He found that it is nocturnal like horti-deorum and that it visits aphids on carnations and roses, and the nectaries of the pepper tree (Schinus molle), rattle-snake weed (Euphorbia setiloba), honey plant (Echium simplex) and Ceanothus cuneatus. The last is a well-known element of the Californian chaparral.

\title{
THE NORTH AMERICAN SPECIES OF THE GENUS HAMATOPOTA.
}

\section{By Charles W. Johnson.}

In the Eastern United States the species of this genus are comparatively scarce, and in all my collecting I have taken only two specimens. Under such circumstances it is often very difficult positively to determine an inadequately described species of the older authors: thus the only species collected in this region was naturally referred to $H$. punctulata Macq., described from Carolina. In preparing recently a faunal paper on the diptera of Florida, my attention was called to four specimens collected by Mrs. Annie T. Slosson, which were very different from Pennsylvania and New Jersey specimens which I had referred to Macquart's species. A careful study shows that the Florida specimens are undoubtedly the true $H$. punctulata, while the more Northern specimens represent a new species. The species may be tabulated as follows:

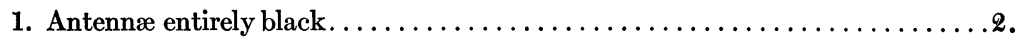
Antennæ with the third joint (except the annuli) red. Front with two subquadrate black spots. Apical band of the wing broad and distinct from the anterior to the posterior margin.................... 
2. Front tibiæ strongly dilated; wings brownish black, very finely flecked with white, apical band broad, slightly curved and reaching the posterior margin of the wing.............................. punctulata Macq.

Front tibiæ scarcely dilated; wings grayish with small, irregular flecks of white, apical band narrow, angulate and not reaching the posterior margin of the

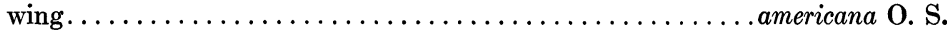

\section{Hæmatopota rara sp. nov.}

Female. Face whitish pollinose, thickly punctated with black, the upper punctures fusing into an irregular spot near the base of the antennæ; lower half of the front shining black, slightly rugose and raised along the upper margin; the upper portion of the front grayish pollinose, with two subquadrate, velvety black spots on each side narrowly separated from the shining portion; a minute central spot also present on the upper part of the front; antennæ black, the first joint considerably thickened, shiny, slightly pruinose on the inner side near the base, third joint reddish, base yellow, annuli black; palpi light yellow. Thorax grayish black, with three pollinose stripes; humeri, a spot above the base of the wing, and the post-alar callosities, brown; pleuræ and scutellum grayish pollinose. Abdomen grayish black, with whitish pollinose posterior margins and spots on the segments similar to those of $H$. americana. Femora and coxæ black, grayish pollinose; anterior tibiæ black, basal fourth white; middle and posterior tibiæ with three black and two white bands unequal in width, the middle black band being about double the width of the others; tarsi black, base of the middle and posterior tarsi white. Stalks of the halteres white, knobs brown. Wings grayish black, with numerous white dots, some of which form ocellar spots, with the cross veins forming the center of the spots; the white apical band broad and extending from the end of the second to the posterior branch of the third longitudinal vein; stigma brown. Length, $7 \mathrm{~mm}$.

One specimen collected by the author at Folsom, Delaware County, Pa., June 12, 1894.

\section{Hæmatopota punctulata Macquart.}

\section{H. punctulata Macq., Dipt. Exot., I, 1, p. 163, 1838.}

As the description of this species is brief and not accessible to many I will redescribe the species more fully:

Female. Face whitish pollinose punctated with black, the upper punctures fusing and forming an irregular transverse stripe extending from the base of the antennæ; lower part of the front shining black, upper portion of the front and vertex black, grayish pollinose, the former with two subtriangular, velvety black spots, very narrowly connected with the shining black area at the lower angle; a minute black spot above at the lower end of an obsolete vertical vitta. Thorax dull black with three very narrow grayish stripes; humeri and sternum grayish pollinose. Abdomen dull black, with grayish posterior margin and two obsolete spots near the 
sides of each segment. Legs black, the tibiæ strongly dilated in comparison with other species, anterior tibiæ with one, and the middle and posterior tibiæ with two narrow bands of white; basal half of the middle posterior tarsi white. Halteres with stalk white and knobs black. Wings a uniform brownish black, finely flecked with white, those toward the base forming narrow crescent shaped markings; apical band prominent and extending from the end of the second to the end of the posterior branch of the third longitudinal vein; the outer end of all the posterior cells margined with white. Length, $6 \mathrm{~mm}$.

Jacksonville, Fla., (Mrs. Slosson); Crescent City, June, (Hubbard), U. S. Nat. Museum. This species was referred doubtfully to Homatopota americana in my first list of Florida Dijeteva, (1895).

I am indebted to the kindness of Mrs. Slosson and Mr. Frederick Knab for the loan of specimens.

\section{BOOK NOTICE.}

Beiträge zur Kenntnis der südamerikanischen Dipterenfauna. Fam. Asilidae. By Professor Dr. F. Hermann. (Abh. der Kaiserl. Leop.-Carol. Deutschen Akad. der Naturforscher XCVI, Nr. 1, pp. 1-275, Tab. 1-5, and with 87 fig. in text, 1912, Halle).

The present work on the Asilidæ of South America covers only the subfamily Laphriinæ, and is largely based on the collection made in Chili, Peru and Bolivia in 1902-1904 by the late W. Schnuse.

The author has worked up this material in a very thorough and comprehensive manner, and his work forms a valuable contribution to our knowledge of the Diptera of that region. The work has also considerable bearing on the North American species. The author considers many of the recognized species of Atomosia to be only varieties of $A$. rufipes Macq., placing in this category A. sayii Johns., mucida O. S., soror Bigot, punctifera Herm., and eupoda Bigot. The author also calls attention to the fact that the true types of the genus Dasyllis, (D. homorrhoa and croceiventris Wied.) are very different from the North American species commonly referred to this genus, such as $D$. grossa, etc. Twenty-one new genera and sixty-one new species are described.

C. W. J. 

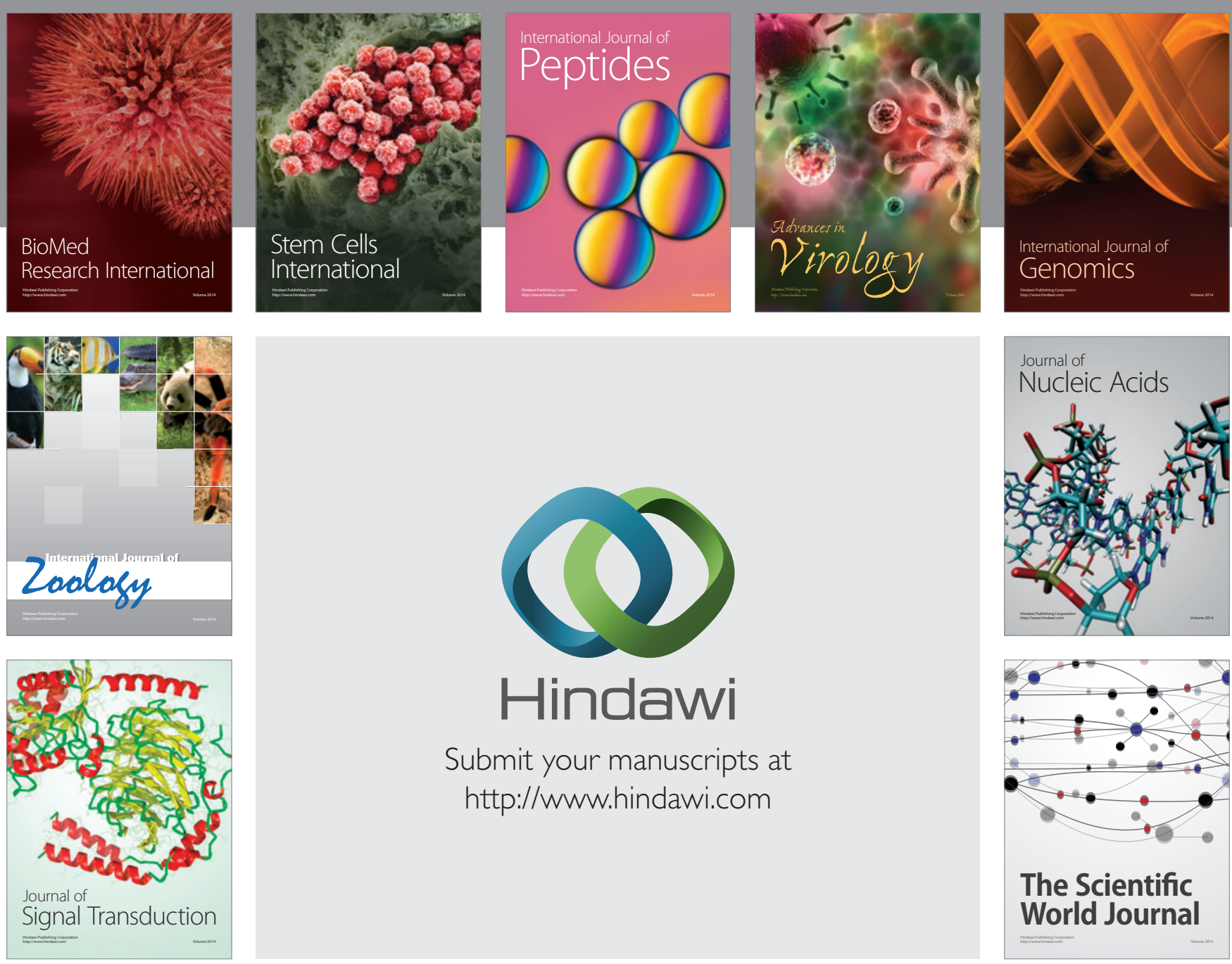

Submit your manuscripts at

http://www.hindawi.com
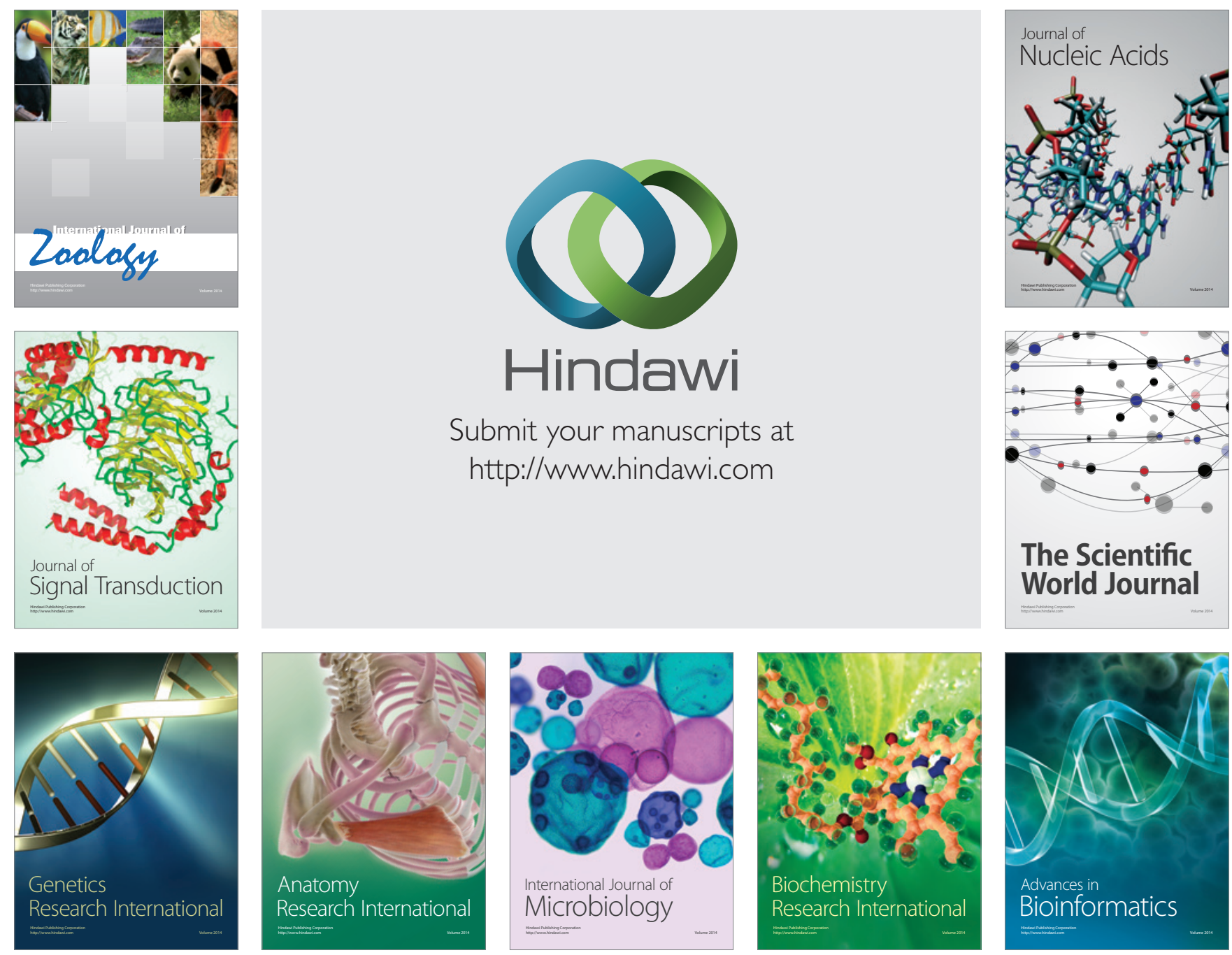

The Scientific World Journal
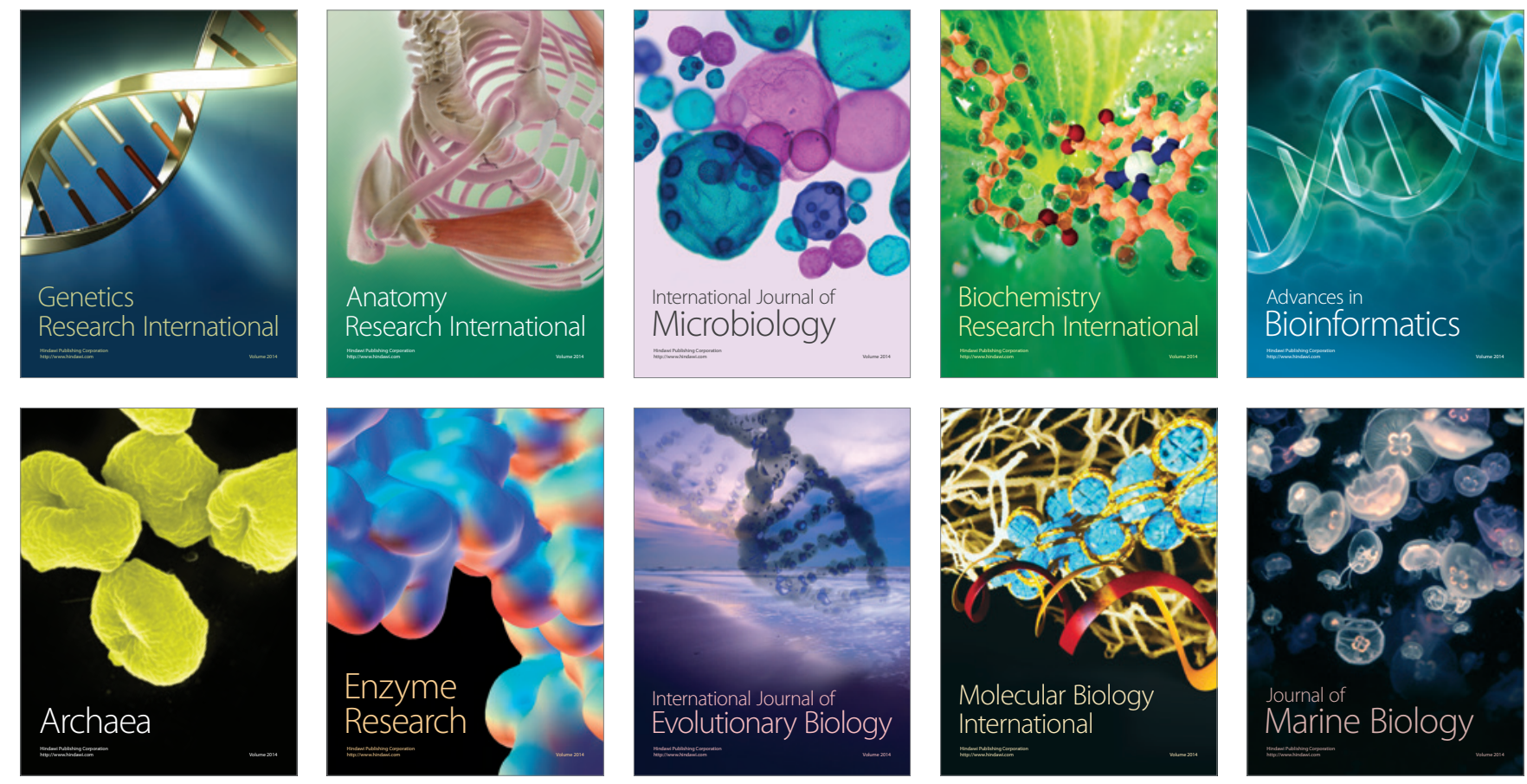